Как видно, лиганд обладает сравнительно хорошей поглощающей способностью и для возбуждения люминесценции достаточно использовать линию ртутной лампы с длиной волны 248 нм.

У всех синтезированных комплексных соединений с данным лигандом наблюдается люминесценция ионов лантаноидов, при этом фосфоресценция органического лиганда отсутствует, что говорит о хорошей передаче энергии от лиганда иону лантаноида.

Наибольшая интенсивность люминесценции наблюдается для комплексных соединений $\mathrm{Eu}^{3+}$, $\mathrm{Tb}^{3+}, \mathrm{Sm}^{3+}$ и $\mathrm{Dy}^{3+}$ (рис.7-9).Одинаковый характер полос испускания и их положения в спектрах люминесценции комплексов с данным лигандом свидетельствует об одинаковой симметрии центров люминесценции, следовательно, об одинаковой структуре координационного узла. Спектры люминесценции лантаноидов различаются только по интенсивности.

\section{Выводы}

1. Получены комплексные соединения $\mathrm{Sm}^{3+}, \quad \mathrm{Eu}^{3+}, \quad \mathrm{Gd}^{3+}, \quad \mathrm{Tb}^{3+}, \quad \mathrm{Dy}^{3+} \quad \mathrm{c} \quad 4-[(3,4-$ диметоксибензил)амино]бензойной кислотой (HL), состав которых соответствует формуле $\mathrm{LnL}_{3} \mathrm{nH}_{2} \mathrm{O}$, где $\mathrm{n}=0-2$.

2.Методом термогравиметрии определены области термостабильности комплексных соединений: для $\operatorname{Ln}(\mathrm{L})_{3} 100-150^{\circ} \mathrm{C}$.

UDC 930.85

ГРНТИ 03.20
3. По данным ИК спектров определен способ координации лиганда с ионами лантаноидов. Координация лиганда осуществляется только по карбоксильной группе.

4.Наибольшая интенсивность люминесценции наблюдается для комплексных соединений $\mathrm{Eu}^{3+}$, $\mathrm{Tb}^{3+}, \mathrm{Sm}^{3+}$ и $\mathrm{Dy}^{3+}$.

5.На основании анализа спектров люминесценции комплексов изученных лантаноидов с данным лигандом можно предположить одинаковую симметрии центров люминесценции, следовательно, и одинаковую структуру координационного узла.

\section{Литература:}

1.Ельяшевич М.А. Атомная и молекулярная спектроскопия. - М.: Эдиториал УРСС, 2001. - 896 c.

2.Золин В.Ф. Редкоземельный зонд в химии и биологии/ В.Ф. Золин, Л.Д. Коренева, - М.: - Наука, - 1980. - 350 c.

3.Джардималиева Г.И. Макромолекулярные карбоксилаты металлов / Г.И. Джардималиева, А.Д. Помогайло // Успехи химии. - 2013. - Т. 77. - С. 270315.

4. Гарновский А.Д. Современные аспекты синтеза металлокомплексов. Основные лиганды и методы / А.Д. Гарновский, И.С. Васильченко, Д.А. Гарновский. - Ростов-на-Дону: ЛаПо, 2010. - 335 с.

\title{
HISTORICAL REASONS OF THE CHINESE KAZAKHS' MIGRATION TO TURKEY AND EUROPE (BASED ON THE SU BEIHAI'S MANUSCRIPT GENERAL HISTORY OF THE KAZAKHS)
}

Kaiyrken Tursynkhan Zakonuly ${ }^{1}$, Makhat Danagul Akhmetkarimkyzy ${ }^{2}$

${ }^{1}$ L.N. Gumilyov Eurasian National University, Satpayev Str., 2, 010000 Nur-Sultan, Kazakhstan

Doctor of Historical Sciences, Professor ORCID: 0000-0002-3808-4989

${ }^{2}$ L.N. Gumilyov Eurasian National University, Satpayev Str., 2, 010000 Nur-Sultan, Kazakhstan

Doctor of Historical Sciences, Professor. ORCID: 0000-0002-8038-2680

\section{ИСТОРИЧЕСКИЕ ПРИЧИНЫ ПЕРЕСЕЛЕНИЯ КАЗАХОВ ИЗ КИТАЯ В ТУРЦИЮ И ЕВРОПУ (НА ОСНОВЕ РУКОПИСИ СУ БЭЙХАЯ «ОБЩАЯ ИСТОРИЯ КАЗАХОВ»)}

Кайыркен Турсынхан Законульг ${ }^{1}$, Махат Данагүл Ахметкәрімқызы ${ }^{2}$

${ }^{1}$ Евразийский национальный университет им. Л.Н. Гумилева,

ул. Сатпаева 2, 010000 г. Нур-Султан, Казахстан

Доктор исторических наук, Профессор. ORCID: 0000-0002-3808-4989

${ }^{2}$ Евразийский национальный университет им. Л.Н. Гумилева, ул. Сатпаева 2, 010000 г. Нур-Султан, Казахстан

Доктор исторических наук, Профессор. ORCID: 0000-0002-8038-2680

DOI: $10.31618 /$ ESU.2413-9335.2020.6.76.941

\section{ANNOTATION}

The article presents the reasons for the mass migration of the Kazakhs living in the People's Republic of China to foreign countries in 30`s of twentieth century, including India, Pakistan, Turkey and Europe. The study compares, examines, and correlates different data and the facts in Part IV of the comprehensive study by Chinese scholar Su Beihai General History of the Kazakhs, and the reasons, motivation, circumstances, and fate of the relocation were systematically recorded. Su Beihai saw the nomadic Kazakhs passing through Gansu and Qinghai provinces of China and collected a lot of material about them. Previously, due to strict censorship of the history of 
minorities in the People's Republic of China, the aforementioned four-volume book by Su Beihai, General History of Kazakhs, was banned for publication in China. In this work, the author, as a historian and representative of the ruling nation in the country, gives an objective assessment of the history of Kazakhs who moved from Kumil (Hami) and Barkol regions of Eastern Xinjiang. Unable to bear the national oppression of local Chinese rulers and the violence of communist authorities, people migrated to Eastern Anatolia in search of freedom. This is one of the greatest tragedies in human history, of which little is known until now. Therefore, the data of this period and the role of research on them in revealing historical truth are special. Much of the information we use in this article to uncover the facts of this history is taken from previously unpublished original data from Su Beihai's manuscript. Even today, the problem of minorities in China is not completely solved. Thousands of indigenous people born and raised in Xinjiang still live abroad.

\section{АННОТАЦИЯ}

В статье приведены причины массовой миграции казахов, проживавших в Китайской Народной Республике, в зарубежные страны в 30-е годы XX века, в том числе в Индию, Пакистан, Турцию и Европу. В исследовании сопоставляются, анализируются и соотносятся исторические источники и факты IV части комплексного исследования китайского ученого Су Бэйхая «Всеобщая история казахов», систематически фиксируются причины, мотивы, обстоятельства и дальнейшая судьба переселения. Су Бэйхай наблюдал за кочевниками-казахами, проходящими через китайские провинции Ганьсу и Цинхай, и собрал о них много материалов. Ранее, в связи с жесткой цензурой истории меньшинств в Китайской Народной Республике, вышеупомянутая четырехтомная книга Су Бэйхая «Общая история казахов» была запрещена к публикации в Китае. В данной работе автор, как историк и представитель правящей нации в стране, дает объективную оценку истории казахов, переселившихся из Кумыльского (Хами) и Баркольского районов Восточного Синьцзяна. Не выдержав национального гнета местных китайских правителей и насилия коммунистических властей, люди в поисках свободы мигрировали в Восточную Анатолию. Это одна из величайших трагедий в истории человечества, о которой до сих пор мало что известно. Поэтому данные этого периода и роль исследований по ним в раскрытии исторической правды являются особенными. Большая часть информации, которую мы используем в данной статье для раскрытия фактов этой истории, взята из ранее неопубликованных оригинальных данных из рукописи Су Бэйхая. Даже сегодня проблема меньшинств в Китае не решена полностью. Тысячи коренных жителей, родившихся и выросших в Синьцзяне, до сих пор живут за границей.

Keywords: the Chinese Kazakhs, Shinghai Revolution, Soviet Union, Stalinist repressions, communists of China, Shen Shicai, East Xinjiang, Kumil, Barkol, Kozhaniyaz uprising.

Ключевые слова: казахи в Китае, Синхайская революция, Советский Союз, сталинские репрессии, коммунисты Китая, Шэнь Шицай, Восточный Синьцзян, Кумил, Баркол, восстание Кожанияза.

Introduction. The $30 \mathrm{~s}$ and $40 \mathrm{~s}$ of the twentieth century were the most deplorable and tragic years in the life of the Kazakhs living in China. Hundreds, thousands of families with old people, women and children left their homeland in East Turkestan (Xinjiang) in the foothills of the Altai and Tien Shan Mountains and had to relocated to Turkey through India and Pakistan, overcoming the snowy summits of the Himalayas. It was the longest and most tragic journey in human history. The reason for their relocation abroad was, firstly, the violence of local Chinese government officials at the time, and the second, Stalinist policy in the persecution of the Soviet Union Kazakhs bordering Chinese Xinjiang region. The Soviet government accused the Kazakhs in China of trying to establish a major Muslim state in China with Chinese Dungans and Uighurs in support of Japanese imperialism. The Soviet Union secretly sent troops across the border to help suppress the East Turkestan government, which had been formed in Kashgar in 1933, and used local governors of Xinjiang to pressure the Kazakh tribe leaders and force them to give up their weapons and turn each other in. Thus, the innocent were cruelly punished. As a consequence, the long history of Kazakh refugees and their long journey, which had not been described anywhere before, began in the depths of Inner Asia via the Himalayas, India, Pakistan and the Indian Ocean to Turkey. However, the Kazakh refugees and some historians who were interested in this incident have never stopped researching it. From time to time, fresh data and views on the subject are being accumulated. As research on the issue deepens, some frozen views and attitudes change.

The methodology of the problem. The study used memoirs of those who saw and intervened in events that happened in East Xinjiang in the 1930's and 1940 's, and materials related to Xinjiang local history published between 1981 and 1991. Witnesses were also interviewed. When using the available data, comparisons, determination of the actual value and reliability were performed. Earlier published research works on this subject have been critically reviewed, and attention has been given to the study of aspects that were not covered or mentioned in them. Methods of generalization, systematization, comparison, regularity, and comparative analysis were used in the research.

Main part. Many memorials, historical essays or memoirs of the Kazakh immigration originating in China in the 1930's were first published by the Kazakhs in China. This event, which left a special mark in the history of the Kazakh people, is described in the "The Transition of Barkol Kazakhs to the East" by Karim Akrami [1], who is a living witness, K. Ospanov`s "Barkol Events" [2], and in the memorial work "From Homeland to Anadolu" by Khalifa Altai, a prominent representative of the Kazakh diaspora living in Turkey. The voluminous historical poem Munly Zar ('Mournful 
Cry') by Muhametkali Khalit, written in 1981, was published in 1989 in the Xinjiang almanac The Material of Ili History [3]. In addition, in 1993 a collective study entitled "History of the Xinjiang Kazakhs Migration” (新疆哈萨克族迁徙史) was published [4].

This historical event is also featured in collections. For example, the book General Situation of the Kazakh Barkol Autonomous Region, published in 1984, describes migratory movements from Barkol region of East Turkestan in 1935-1940s [5], in the memoirs Fifty years of Xinjiang, written by B. Shahidid and published in 1986 in Beijing, describes the reasons for the KumylBarkol event in 1933-1935, the Kumyl uprising led by Kozhaniyaz, the Dungan invasion, and the UighurKazakh farmers' uprising against the rule of Jin Shuren and Sheng Shicai [6]. One of the most comprehensive and systematic studies of the history of the Kazakhs of East Turkestan in recent years is a documentary historical essay Holy Nomad by Apetai Mukarap. In this work, the author describes the origin of the nomad, the number of flows of people, routes and places of stopping and settling, the number of families, the reasons for each nomad, the relationship between people traveling to Gansu, Qinghai and other countries with the locals, the relationship between every nomad, difficulties and the suffering they experienced, and their misery. We consider this work to be the only complete and objective work with regard to the bloody and sad history of the Kazakhs, who were persecuted by the extraneous Xinjiang government in the $30-40$ s of the twentieth century [7]. At the same time, in 2016, "Orkhon" Publishing House in Almaty published a book by Doctor of Historical Sciences, Professor Abduvahap Kara, Relocation of Kazakhs to Turkey (oral data from Kozhan Vizir aksakal), based on oral data from Kozhan Vizir, who was in the move of the Kazakhs from East Turkestan to Turkey in the 30-40s of the twentieth century [8].

In the historical study of T. Zakenula Forgotten Republic: People's Liberation Movement of the Kazakhs in Eastern Turkestan. 1940-1949, published in 2008 in the series of multi-volume Kazakh People's Liberation Movement, it is indicated that the main reason for the people's liberation movement of the local population is that in 30-40 years the Kazakhs had to leave their homes in Kumyl and Barkol. It used the mentioned memoirs by $\mathrm{K}$. Akrami and the manuscript by $\mathrm{Su}$ Beihai, about which we will talk further [9].

In-depth study of the history of resettlement of Kazakh peasants from Eastern Xinjiang to other countries was conducted by Chinese scientist $\mathrm{Su}$ Beihai. In $4^{\text {th }}$ volume of his book General History of the Kazakhs, which was not published in China due to censorship, he writes about the Kazakhs who moved in the 30-40s to the areas of Gansu and Qinghai, then further to India, Pakistan and Turkey in a separate chapter entitled The resettlement of the Kazakhs from Xinjiang to Gansu, Qinghai and far abroad under the rule of Sheng Shicai. He regarded this event as a

- Ukirdai - rank corresponding to the status of significant part of the history of the Kazakh people. It describes how the Kazakhs first moved from Altai to Kumyl and Barkol, the names of the settlers, their ru (belonging to a certain tribe), the number of family. It then describes the life of Eliskhan, a famous personality from the Barkol Kazakhs, the murder of his father Alip ukirdai*, the policy of the Sheng Shicai's government towards Eliskhan and his people, and the actions of the active communist Abai Kasymuly, who came from the Soviet Union. Further described are the beginning of the resettlement of the Kazakhs in the winter of 1935 , the opposition of the regional governments, the leaders of each resettlement and their names, ru, the number of family, i.e. people, their relations with local governments and peoples, and the difficulties they experienced. In addition, one part is devoted to how the Kazakhs, in agony, migrated to other foreign countries [10]. The manuscript was brought to Kazakhstan because the author could not publish it in China for obvious reasons. At the moment this manuscript is in research by scientists of L.N. Gumilyov Eurasian National University and is being translated into Kazakh language.

After the revolution of Xinhai in the early twentieth century, regions in northwest China such as Altai, Tarbagatai (Tacheng) and Ile (Ili), where the Kazakhs lived, moved to the administrative region of Xinjiang. Violence by Chinese officials and the military and national discrimination has generated distrust and resentment among Kazakhs. That is why Kazakhs from Barkol led by Kozhaniyaz participated in the Uigur peasant uprising in Kumil. After this time the uprising stalled, the group of elders and the people who followed them were forced to go further to distant countries. Such barbaric policy, which forced the Kazakhs to leave their ancestral land and move on the road, continued until the late 40s. These events are fully reflected in scientist $\mathrm{Su}$ Beihai`s work.

The Kazakhs began to settle again in the Barkol area in the $80 \mathrm{~s}$ of the nineteenth century. According to historical data, in 1883 the very first to move from the Altai were about a hundred families under the leadership of naiman Daldebai and Kokdarkhan, who passed through Zhemsary, Mori and Mount Baytik to the Barkol (Balikun) area of Eastern Xinjiang. At the same time, there are reports that a number of people moved here under the leadership of kerey Kamysbay and Zhamysbay brothers. Then, in 1889-1890, two hundred families, headed by Amrit, Zharmysbai, Sydyk, Shilgaubai, Tokpak, Balpanak and Shayakhmet, Smail, who were from zhanteke ru of kerei, moved from Altai to Barkol area. In 1895, Kairbai, from ru zhadik of kerei, and Shulenbai, from ru sarbas, moved to Barkol with two hundrer families. During 1912-1913 Nogaibai, Buratai and Tarni relocated 1000 families to Barkol. In 1917, three hundred more families moved from Tarbagatai and Altai to Barkol. By 1927, two thousand families from Jemsara, Mori and Sonji (Qitai) districts in eastern Urumqi moved to Barkol. From 1933 to 1935, five hundred and fifty families from Altai, Tarbagatai, Shonji and Mori moved to Barkol. 
Thus, before Shen Shicai came to power in 1933, about four thousand five hundred kazakh peasants lived in Barkol [5, p. 46]. Assuming that there are six people in each family, by 1933 the number of Kazakhs inhabiting Barkol had reached twenty seven thousand.

Kazakhs from Barkol at the time were headed by Kamysbai and Zhamysbai brothers, who we mentioned above. According to historical data, Kamysbai had two wives. The eldest wife gave birth to an eldest son Kaisa in 1880 and the youngest son Alip in 1883. The younger wife gave birth to his third son Kozhabergen in 1885 and his fourth son Kozhakyn in 1887. These four Kamysbai sons started to lead Kazakhs from Barkol as soon as they were ready for it. Among them, Alip had the strongest influence. His mentors and assistants were mainly from the Kaisa, Shulenbai, Munaybai and Elekbei rus. At the time, regions in Eastern Xinjiang such as Barkol, Kumyl, Mori and Shonji were under their control [1, p. 54]. The data used by K. Akrami is also used by Professor Su Beihai in his work. Looking at this, we can see that Su Beihai made full use of K. Akrami's article In Historical Materials of Ili. Su Beihai had a great deal of trust in K. Akrami's article. Because K. Akrami fled the Soviet Union as a child, lived in Urumqi since the 1930s and held positions of responsibility in the Shen Shicai`s government. In addition, thanks to his knowledge of Russian and Chinese, he used archival documents directly. Su Beihai used the manuscript Resettlement of Barkol Kazakhs to the East written by Kazakh Karim (柯仁) as the main source of information about Shen Shicai's violence against Kazakhs from Barkol and Abai's actions among the Kazakhs.

Karim (Karim Akrami - aut.) in 1939-1941 worked as an interpreter in the organization of public security of the Barkol district and agitation armies of the Barkol district to counteract the Japan. In 19461948, he headed the Delegation for the Return of Xinjiang Kazakhs to Their Homeland and Assistance and served for two years at the Gansu, Qinghai and Xinjiang borders. In some of the events that he describes, he was an eyewitness, while others were collected during his research. For this reason, he says: "This data has never been published anywhere before" [10, p. 929]. Some of the information we have provided below is taken from the aforementioned K. Akrami`s memoirs and $\mathrm{Su}$ Beihai's General History of the Kazakhs. It should be noted that in addition to K.Akrami`s works, Su Beihai used such works as Memories of the arrival of Kazakhs in Gansu (Hasake ru Ganji-哈萨克入甘记), written by Ma Linbang and published one after another in the journals Xibeilunheng - 西北论衡 and Xin Xibei - 新西北 in 1942-1944 in Gansu [11], [11, №2-5]research paper "The study of the Kazakh nation and the process of their arrival in Gansu" (Hasakzu zhi yanjiu jiqi ru Gan jingguo - 哈萨克族之研究及其入甘经过), published by Guo Shunan in 1942 in the journal Zhongguo bianjiang - 中国边疆 [12], the article "Scriptures on the arrival of Kazakhs in Gansu and their return to Xinjiang" (Hasakezu ru Gan ji fanxin jilüe哈萨克族入
甘记返新纪略), published by Gu Bao in 1948 in the journal Xinjiang luncong - 新疆论从 [13] and others.

In 1912, after the Xinhai Revolution, the mayor of Urumqi, Yang Zengxin, who had previously held the positions of an observer at the border and chairman of the Xinjiang region, in order to attract local forces to his side, that is, the feudals of each nation, brought to Urumqi and taught the Chinese language to Sharipkhan, the younger brother of Prince Alen of Altai, Eliskhan, the elder son of the ataman of Eastern Xinjiang Alip, and Kizir, the son of Tarbagatai commander of a group of one thousand people Mamybek. As the situation in Xinjiang later became precarious, in order to keep the locals under his influence, Yang Zengxin put Shariphan and Kizir in responsible positions, and appointed Eliskhan commander of the defense garrison of Eastern Xinjiang. At the time, Eliskhan had two hundred fully armed soldiers.

In 1931, when Kozhaniyaz (uighur) started a rebellion against Jin Shuzhen`s government in Kumyl region (Hami) of Tukhulu (Tuhelu), Alip believed that he is one of the influential religious figures who has the support of religious forces in Xinjiang, and that through him it was possible to achieve the intended goals, so he sent him a hundred horses, a thousand sheep, and supported him both spiritually and morally. When Jin Shuzen found out about the situation, he immediately appointed Sheng Shicai as commander in chief in Eastern Xinjiang and sent him against Kozhaniyaz and Ma Zhunin, who came to his aid from Gansu and Qinghai. In his memoirs, K. Akrami writes: "Alip counted Sheng Shicai freeloader and weak, in addition, he had four thousand family, several hundred weapons, so he was not afraid of Sheng Shicai's revenge and did not help him, and tied his people up. Alip was also in conflict with Mongolia. Now the wrath of the Xinjiang rulers has been aroused. Thus, he fell into dissatisfaction with the Soviet Union, which supported Sheng Shicai in Xinjiang" [1, 55-57 pp.].

In 1933, on April 12, Sheng Shicai defeated Jin Shuzhen and took full control of the military administration of Xinjiang. Since the Soviet Union, Mongolia and the Xinjiang authorities wanted to maintain the calm of the southern and northern trade routes, as well as the calm of the routes leading west and east, he was going to relieve Eliskhan of his position as commander of the border guard detachment and confiscate all Alip`s weapons. Sheng Shicai had this idea a long time ago. However, the Alip forces in the east were strong, there were four thousand families. His troops, consisting entirely of Kazakhs, were strong in battles. It was hard to resist them immediately. Knowing that he could be easily destroyed from the inside, he ignited the strife between Alip and his halfbrothers. He spread lies among people that "Alip and Kaisa, the children of the older wife, control everything and have the best lands, while the children of the younger wife Kozhabergen and Kozhakyn were left with nothing". Having taken this to heart, Kozhabergen and Kozhakyn started looking for better lands elsewhere in Barkol. Mongolia also wanted to take advantage of this situation because it had been waiting 
for this for a long time. In order to divide them from within, Kozhabergen and Kozhakyn were offered to settle in the Alatau region that belonged to Mongolia. When they heard that Sheng Shicai sent troops to Alip and Kaisa, being afraid, accepted the offer of Mongolia and moved with six dozen families. When they heard this news, Alip sent Eliskhan and two hundred men after them.

Seeing that Kamysbay's children were in conflict with each other, Shen Shicai decided to destroy them one by one and sent reinforced regiments of one thousand one hundred soldiers to villages where men were absent. This state army was divided in two: one group followed those who moved to Mongolia, while the second group took Alip's aul (village) surrounded by them.

As stated in the historical data, when they arrived, the Alip was not at home. He was called by a friend whose surname was Ma. As soon as Alip crossed the threshold of his house, Shen Shicai's thugs shot and beheaded him, then brutally killed over two hundred people from sixty families. So innocent old men and children of the Kazakhs were exterminated and left to be eaten by wild animals.

When Eliskhan heard the news that his parents and all his relatives had been murdered, he returned with his younger fathers and chased the army that followed them to the Mori River. However, he could not catch up with them and so he fired on the local Chinese inhabitants. Now the struggle between Sheng Shicai and Alip has become a Chinese-Kazakh national conflict. At that moment Sheng Shicai sent an armed army three times to further advance and destroy the Kazakhs. However, these armies could not defeat Eliskhan.

In May 1934, Eliskhan summoned all leaders, rulers of ru (tribes) and prominent figures from the regions of Altai, Kumyl and Urumqi to commemorate the death ("as") of his father Alip. He was expecting the arrival of 1000 people and for that he built 100 yurts, sent 300 cattle and sheep for slaughter. Sheng Shicai also sent his man with a letter in which he explained that it was not his desire to kill Alip, but the antics of his soldiers, and that the main criminal who fired on Alip was shot, and called for reconciliation. The leader of the Altai region Sharipkhan also sent him a letter in which he asked not to make in vain enmity with Sheng Shicai. According to historical data, after the letter was read out to the guests, Eliskhan said to the audience the following:

"Sharipkhan asks me to reconcile with Sheng Shicai. It's like asking me to surrender my weapon, bow down to my father's killer, give him my head to be cut off. How can I agree to that? If Sharipkhan himself joined us, if we were all like one, how would a tramp like Sheng Shicai manage to hit us? Our Kazakhs will never be reunited, even our brothers are at war with each other, we are ready to become easy prey for others. Sheng Shicai took advantage of this situation and drowned my village in blood, killing two hundred of my people. How do I accept that?! It was Shen Shicai who incited Kozhaniyaz and Ma Junin to feud with each other. His goal is to kill us first, as we are armed, and then he will kill Sharipkhan and everyone here with a bloody hand. That's why I cannot give my gun to Sheng Shicai. Everyone here are respected aksakals (esteemed elders) of their peoples. I have gathered you here for two reasons: the first is to commemorate the death of my father, and the second is to say goodbye to you. I cannot reconcile with Sheng Shicai. He is my irreconcilable enemy. I will fight him for as long as I can. Of course, my strength is small, I cannot say that I will strike him hard. I am looking for support in the east. Then when I come back, I want to do the same thing to Shan Shicai that he did to me. Until Sheng Shicai dies, the Kazakhs and you all will have no peace" [1, p. 60].

Sheng Shicai's representative, who attended the wake, reported to him on the situation. Shen Shicai was embraced by fear, and he begins to look for ways to counter it. In order to keep Eliskhan out of the east, he took the following measures:

1) realizing that he is not strong enough, he takes one full regiment from the Soviet Union and has it in Kumyl to guard the eastern gates of Xinjiang;

2) Sheng Shicai told them that Eliskhan's father and eldest father, all of them were thieves who robbed all the traders in the south and north and along the Silk Road, and that he had killed people from Eliskhan's aul (village) at the will of all people. He urged them to break off contact with Eliskhan, otherwise they would suffer the same fate as Eliskhan;

3 ) instructed the assembly to confiscate all weapons from the public;

4) established the Barkol department of the Kumyl regional administrative body. Appointed kazakh Abai Kasymuly, who arrived from the Soviet Union, as head of the department, and took the local Kazakhs under strict control;

5 ) in order to distract people's attention, he bought a lot of things through the Soviet-Chinese joint trading company SOVSINTORG (“СОВСИНЬТОРГ") and opened a fair in Barkol;

6) he assembled a propaganda group led by Abai, campaigned for Barkol, and expected people to move east with Eliskhan.

In these difficult times of 1934, when the people's calm was disrupted, closer to winter the Adubai and Tungishbai auls (settlements) in Barkol moved to the Gansu region. The people, who had been left behind and were waiting for any news, decided to follow them since they had not heard any bad news from them. Thus, after Eliskhan came under severe pressure from Sheng Shicai, he and a man named Zaiyp Taizhi moved a thousand families each to Gansu and Qinghai near Tibet, fighting all the way against Sheng Shicai's air forces and motorized divisions [2].

K.Akrami writes in his memoirs that Eliskhan moved in September 1935, and only 500 families joined him, while his younger fathers Kozhabergen and Kozhakyn did not move. Kozhabergen and Kozhakyn did not relocate because they believed the false statement made by Sheng Shicai that he would keep the people and livestock of those who would stay. In fact, Shen Shicai blacklisted all Alip`s guests who attended 
the wake and intended to exterminate them [1, p. 62].

In the spring of 1935, Abai arrived at Barkol with fifty servants under the pretext of calming the remaining population. The remaining folk leaders under the Kozhabergen's command meet them and constructed five yurts, and every day they present one ram. Abai alone received five hundred rams, a good horse, a lynx coat and a bear's skin. Tired of war, the people tried to tame Abai in this way. Having accepted all these offerings, Abai took with him seventeen people, such as Kozhabergen, Kozhakyn, Botabai and Akimbai, under the pretext that there was one thing to do in the Kumyl regional akim administration (city hall). Upon arrival in the city in the Barkol region, Abai shackled them all, took them to Urumqi and handed them over to Sheng Shicai. Shen Shicai shot them all without consulting anyone. Thus, all those who believed in Sheng Shicai were brutally killed.

Abai applied the so-called policy of "destruction of three", which the Soviet Union used in Kazakhstan in 1929-1933. The purpose of this policy was to prevent the resettlement of the Kazakhs and their resistance, as well as to deprive them of mobility by, firstly, confiscating weapons, so that there would be no resistance, secondly, confiscating horses, so that there would be no movement, thirdly, depriving them of transport, so that there would be no resettlement, so that they would not be allowed to go to wintering, but to establish a collective farm (kolkhoz). That is why Barkol Kazakhs called him "greedy Abai, the destroyer of three". In fact, it was Sheng Shicai who unmistakably copied and applied this policy.

This is what $\mathrm{Su}$ Beihai writes about this: "After Shen Shicai came to power in 1933, he used political terror and merciless pressure against Kazakhs. Thus, from 1936 to 1939, many Kazakh auls (settlements) moved to the Qilyan-Shan area in the Gansu region. At that time, Kazakh leaders and peasants assumed that, on the one hand, the regions of Gansu-Qinhai were under the control of the Ma Bufan dynasty, who were also Muslims, and, on the other hand, that they would help and receive them. Thus, in 1936 four thousand families, about thirty thousand people, went to Gansu Qinghai in six streams" [10, 905-906 pp.].

When Shen Shicai received the news that Barkol Kazakhs had begun mass resettlement to the east, he urgently assembled units of pursuers, divided into six streams and let them follow the people. Many Kazakhs came under fire from the pursuers. The old men, women and children were ruthlessly killed. The pursuers took away their cattle and livestock. However, the settlers did not change their plans, and repulsed the Sheng Shicai's troops and forced them to bear large losses. When the resettlers reached the land called Lom, the six streams united into three. Skilful leaders and armed troops formed a guard ahead of them, and behind them - the defense, and moved so unstoppable. At this time, ten warplanes and over two thousand motorized military forces sent by Sheng Shicai were chasing them. The resettlers lost a lot of people and livestock. Thanks to the strong resistance of the defensive detachment, the battle lasted only three days, and many of the resettlers survived. Nevertheless, hundreds of
Kazakhs were killed because of the continuous firing of enemy planes. Some were captured and missing. A lot of cattle were lost. Out of two hundred thousand sheep only one hundred forty thousand remained, and out of twenty thousand horses only ten thousand. All thirty thousand camels and ten thousand cows either died or fell into enemy hands. All of this has had a serious impact on the lives of the resettlers [10, p. 907].

According to historical data, the vast majority of Kazakhs who moved to Gansu in 1938 moved to Qinghai. In 31 year, according to the chronicle of Mingo (1942), the total number of Kazakhs who stayed in Gansu at that time was 577 families, or two thousand five hundred and ninety people (it does not include the number of Kazakhs on the border of Saydam and Gansu-Tsinghai regions) [10, p. 911]. For the first time Kazakhs moved to the Qinghai region in late 1937 and in the spring of 1938. They were headed by Adybai, Zaiyp, Eliskhan, Sultansharip, Ismayil and Tungyshbai. At that time, according to the local government, over twenty eight thousand Kazakhs moved to Tsinghai ${ }^{25}$.

This agony lasted two-three years, and only a small part of the exhausted Kazakhs reached their destination. It is not known how many people died from hunger, thirst, diseases, poisonous gases and those who went missing. The Kazakhs believed in Ma Bufan and hoped for his support, as he was also a Muslim, but Ma Bufan began to take revenge on the Kazakhs for the fact that in 1931-1933 some Kazakhs fought against him on the side of Sharipkhan, and he had a disagreement with Kozhaniyaz. Thus, Eliskhan's plan to unite with the militarist of the Gansu-Qinghai region $\mathrm{Mu}$ Bufan against Sheng Shicai and establish a Muslim state in Xinjiang failed. The Kazakhs who followed them were exhausted, ill-treated and in trouble.

Those who were left behind were very worried that the people were terrorized by Sheng Shicai and forced to move to other people's lands. At that time, a group led by a prominent figure from the Altai Kazakhs, Dalelhan Sugirbayev, went after them to persuade them to return to their homeland.

Dalelkhan was in the Gansu Qinghai region until 1941 with the aim of agitating the people "to acquire peace and return to their homeland". But Dalelhan heard from them: "We respect you personally, you expressed your sincere intentions and were honest, you passed on the words of your government. But we do not believe this government. So don't try to get us back, you better come back on your own". As a result, Dalelhan was dissatisfied and returned with a heavy heart. Before he left he wrote them a long poem, hoping that it would affect them somehow. Here are some lines from these poems: lakes?

Where are the green mountains, the beautiful

Where are the lands covered by the green carpet? Full of animals, a native land like paradise,

Where are your people, Abak's twelve sons?

Where is the untold wealth?

Where are friendly friends and...

Fast horses?

Where are the people and relatives?

Where is the value of human dignity? 
Having lost all this,

How far are you going?

You left it without hesitation,

You will mourn those days.

Where you will find caring friends,

When hard days come?

However, the deeply disappointed people did not show cordiality to it either. The resettlement of people in Gansu and Qinghai also hit those left behind. After the mass resettlement of Barkol Kazakhs, there were disturbances among the people. Kazakhs, who were in the foothills of the Altai, Tarbagatai, Ile and Erenkabyrga mountains in the area of the Mongolian desert, were very worried about their future fate.

Conclusion. The Sheng Shicai government, seemingly populist and internationalist, has pursued a tough policy toward the Xinjiang people. He was terrified that the people would come together and unite to oppose him and seize power. Because the people were going for it. In the end, Eliskhan's movement was in a sense a protest against the government. Thus, a violent national liberation revolution was ripening against the openly repressive policies of Sheng Shicai.

Ospan Batyr Islamuly led the national liberation revolution since 1941. Common in Ile, Altai, Tarbagatai and the foothills of Tien Shan, this revolution was later suppressed by the Soviet Union and China, without finding international support because it was not in the interests of the communist authorities. The next migration of Kazakhs from Xinjiang took place in 1949 after Chinese Communists occupied Urumqi, and in 1950 when Ospan Batyr was captured and shot. This time, Kuomintang officials and their families, as well as foreign diplomats who did not want to surrender peacefully, left the region. The migration of Kazakh refugees from Altai and Eastern Xinjiang reached the Republic of Turkey in 1952-1956 with many difficulties, dangers and casualties. Most of the Kazakh diaspora living today in Turkey and Europe are descendants of Kazakhs who left the Chinese province of Xinjiang (Eastern Turkestan) during these turbulent years.

\section{References}

[1] Akrami K. Barkol qazaqtarynyn shygysqa auuy [Relocation of Barkol Kazakhs to the East], Materials of Ile History. Ghulja, 1987. №3.

[2] Ospanov K. Barkol oqigalary [Barkol events], Materials of Xinjiang History, 1986, №18, 136 p.

[3] Khalit M. Munly zar (tarikhi poema) [Mournful Cry (Historical poem)], aterial of Ile History, Ghulja, 1989, №5, 109-241.

[4] Xīnjiāng hāsàkè zú qiānxǐ shǐ (Xinjiang Kazakhs`s history of migration), Urumqi, Xinjiang University Press, 1993, 297.

[5] General Condition of Barkol Kazakh Autonomous District, Collective work, Urumqi, Xinjiang People's Publishing House, 1984.

[6] Shahidiy B. Xinjiangning 50 yili (50 Year of Xinjiang), Beijing Milletler nashiryati, 1992, 800.

[7] Mukarap A. Kieli kosh [Holy Relocation], Beijing, Nations Publishing House, 2012, 796.

[8] Kara A. Qazaqtardyn turkiyaga koshi (Kozhan uazir aksakaldyn auyzsha derekteri) [Migration of Kazakhs to Turkey (Kozhan Vizir Aksakal`s oral data)], Almaty, "Orkhon" Publishing House, 2016, 128.

[9] Zakonuly T. Umytylgan respublika: Shygys Turkistan qazaqtarynyn ult-azattyq qozgalysy. 19401949 zhzh. [The Forgotten Republic: The National Liberation Movement of the Kazakhs of East Turkestan. 1940-1949], Kazakh National Liberation Movement, Vol. 12, Astana, 2008, 185-186.

[10] $\mathrm{Su}$ Beihai, Hāsàkè zú tōngshǐ [General History of Kazakhs], Manuscript, 1994, 1095 p.

[11] Ma Lingbang, Hāsàkè rù gān jì (History of Kazakhs' arrival in Gansu), Xibeilunheng, 1942, Vol. 10 , №7.

[12] Guo Shunan, Hāsàkè zú zhī yánjiū jí qí rù gān jīngguò (Research on Kazakhs and their entry into Gansu), 1942, №1.

[13] Gu Bao, Hāsàkè zú rù gān jì făn xīn jì lüè (The arrival of the Kazakhs in Gansu and their return to Xinjiang), Xinjiang, Luncong, 1948, №2. 